\title{
Lysianadioic Acid, a Carboxypeptidase B Inhibitor from Lysiana subfalcata
}

Malcolm S. Buchanan, Anthony R. Carroll, Annette Edser, Melissa Sykes, Gregory A. Fechner, Paul I. Foster, Gordon P. Guymer and Ronald J. Quinn

Lysianadioic acid, a small molecule inhibitor of CPB was isolated from Lysiana subfalcata. It is a new arginine analogue containing an unusual dicarboxylic acid moiety and is the first known example of a small molecule CPB inhibitor isolated from plant origin.

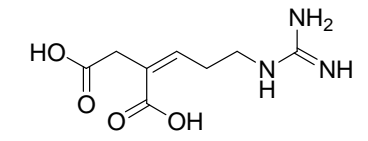

Lysianadioic acid 


\section{Lysianadioic Acid, a Carboxypeptidase B Inhibitor from}

\section{Lysiana subfalcata}

Malcolm S. Buchanan, ${ }^{\mathrm{a}}$ Anthony R. Carroll, ${ }^{\mathrm{a}}$ Annette Edser, ${ }^{\mathrm{a}}$ Melissa Sykes, ${ }^{\mathrm{a}}$ Gregory A. Fechner, ${ }^{\mathrm{a}}$ Paul I. Forster, ${ }^{\mathrm{b}}$ Gordon P. Guymer ${ }^{\mathrm{b}}$ and Ronald J. Quinn ${ }^{\mathrm{a}, *}$

${ }^{a}$ Natural Product Discovery, Eskitis Institute for Cell and Molecular Therapies, Griffith University, Nathan, Queensland 4111, Australia

${ }^{\mathrm{b}}$ Queensland Herbarium, Brisbane Botanic Gardens, Toowong, Queensland 4066, Australia

*To whom correspondence should be addressed. Tel: +61 73735 6006. Fax: +61 73735 6001. E-mail: r.quinn@griffith.edu.au 
Abstract

A new natural product, lysianadioic acid, was isolated from the plant Lysiana subfalcata as a carboxypeptidase $\mathrm{B}(\mathrm{CPB})$ inhibitor. It is a potent inhibitor of $\mathrm{CPB}$ with an $\mathrm{IC}_{50}$ of $0.36 \mu \mathrm{M}$. This is the first known example of a small molecule CPB inhibitor isolated from plant origin. Its structure was determined by NMR spectroscopy.

Keywords: Carboxypeptidase B (CPB); Small molecule inhibitor; Natural products; Lysiana subfalcata; Structure elucidation; NMR spectroscopy 
In a continuation of our investigations to find novel carboxypeptidase inhibitors ${ }^{1-2}$ a carboxypeptidase B (CPB) high-throughput screening campaign was conducted. $\mathrm{CPB}$ is a pancreatic digestive metalloenzyme, which releases basic amino acids from the carboxyl-terminus of proteins or peptides. The search for lead compounds from natural sources which inhibit CPB resulted in a bioactive $\mathrm{MeOH}$ extract of the plant Lysiana subfalcata (Hook.) Barlow (Loranthaceae) being studied further. ${ }^{3}$ Bioassayguided purification resulted in the alkaloid lysianadioic acid (1) (Fig. 1) being isolated as the active constituent. To date the only CPB inhibitors reported from plants have been large polypeptides from potato $^{4-5}$ and tomato. ${ }^{6-7}$ Compound $\mathbf{1}$ is the first known example of a small molecule carboxypeptidase B inhibitor isolated from plant origin. Actinophyllic acid from Alstonia actinophylla was previously suggested to be a carboxypeptidase inhibitor, but the activity observed in a coupled enzyme assay was not confirmed in a direct carboxypeptidase assay. ${ }^{1}$ This paper reports the isolation, structure elucidation and biological activity of $\mathbf{1}$. It is the first known chemical investigation of the plant L. subfalcata.

The plant Lysiana subfalcata (100 g) was ground and extracted with $\mathrm{MeOH}$. This $\mathrm{MeOH}$ extract showed inhibitory activity against the CPB enzyme assay. ${ }^{8}$ A series of partitions were then performed on the $\mathrm{MeOH}$ extract (22.3 g). Firstly a $n$-hexane/MeOH partition, the $\mathrm{MeOH}$ layer was then dried, followed by a $\mathrm{H}_{2} \mathrm{O}: \mathrm{MeOH}(4: 1) / \mathrm{CH}_{2} \mathrm{Cl}_{2}$ partition, the $\mathrm{H}_{2} \mathrm{O}: \mathrm{MeOH}$ (4:1) layer was then dried, then finally a butanol/ $\mathrm{H}_{2} \mathrm{O}$ partition. Testing of the layers directed further purification of the $\mathrm{H}_{2} \mathrm{O}$ layer (14.7 g). The $\mathrm{H}_{2} \mathrm{O}$ layer was filtered through strongly basic ion-exchange resin (DOWEX 1X8-400A) and washed sequentially with $\mathrm{MeOH} / \mathrm{H}_{2} \mathrm{O}$ and $2 \%$ TFA solution. The $\mathrm{MeOH} / \mathrm{H}_{2} \mathrm{O}$ wash contained bioactivity and was subsequently filtered through strongly acidic ion-exchange resin (DOWEX 50WX8400A) and washed sequentially with $\mathrm{MeOH} / \mathrm{H}_{2} \mathrm{O}$ followed by a $5 \%$ aqueous $\mathrm{NH}_{3}$ solution. CPB inhibitory activity was found only in the $\mathrm{NH}_{3}$ fraction. Half of the $\mathrm{NH}_{3}$ fraction (3.98g) was preadsorbed on $\mathrm{C}_{18}$ (04K-4348 Sepra $\mathrm{C}_{18}$ End-Capped Silica) and loaded into a guard column in line with a semi-preparative Betasil $\mathrm{C}_{18}$ HPLC column (Betasil $\mathrm{C}_{18} 5 \mu \mathrm{m} 21.2 \mathrm{~mm} \mathrm{x} 150 \mathrm{~mm}$ i.d.). Isocratic 
conditions of $\mathrm{H}_{2} \mathrm{O} / 1 \%$ TFA for 40 min, then a gradient to $\mathrm{H}_{2} \mathrm{O} / 1 \%$ TFA:MeOH/1\% TFA (9:1) in 20 min (flow $10 \mathrm{~mL} / \mathrm{min}$ ) were used and 120 fractions were collected. A bioactive band eluted early resulting in combining fractions 16-20 (520 mg). This was then chromatographed by gel permeation chromatography using Superdex 30, eluting with water $(0.5 \mathrm{~mL} / \mathrm{min})$ and 60 fractions were collected. There was a spread of activity in fractions $36-47$, which were then combined ( $288 \mathrm{mg})$. The combined fraction then underwent two consecutive Synergi Hydro-RP $80^{\prime}$ HPLC $(4 \mu \mathrm{m}, 10.0 \mathrm{~mm}$ x $250 \mathrm{~mm}$ i.d.) purification steps under gradient conditions over $40 \mathrm{~min}$. Firstly the $288 \mathrm{mg}$ fraction (10 separate injections) using a gradient from $\mathrm{H}_{2} \mathrm{O} / 1 \%$ TFA to $\mathrm{H}_{2} \mathrm{O} / 1 \%$ TFA:MeOH/1\% TFA (9:1) in 30 min followed by a $10 \mathrm{~min}$ gradient to $\mathrm{MeOH} / 1 \% \mathrm{TFA}$ (flow $4 \mathrm{~mL} / \mathrm{min}$ ). The desired fractions were combined (4.5 $\mathrm{mg}$, then secondly a gradient from $\mathrm{H}_{2} \mathrm{O} / 1 \%$ TFA to $\mathrm{H}_{2} \mathrm{O} / 1 \% \mathrm{TFA}: \mathrm{MeOH} / 1 \% \mathrm{TFA}(8: 2)$ in 30 min followed by a $10 \mathrm{~min}$ gradient to $\mathrm{MeOH} / 1 \% \mathrm{TFA}$ (flow $4 \mathrm{~mL} / \mathrm{min}$ ) was used. Lysianadioic acid (1) (1.30 $\mathrm{mg}, 0.0026 \%$ dry wt) eluted with retention time $32.0 \mathrm{~min}$.

Lysianadioic acid (1) was isolated as an optically inactive amorphous solid. ${ }^{9}$ A pseudomolecular ion in the positive HRESIMS at $m / z 216.0983(\Delta 1.9 \mathrm{ppm})$ allowed a molecular formula of $\mathrm{C}_{8} \mathrm{H}_{13} \mathrm{~N}_{3} \mathrm{O}_{4}$ to be assigned to 1. The natural product was analysed using a series of one and two-dimensional NMR experiments in order to determine its structure. The ${ }^{1} \mathrm{H}$ NMR spectrum (Table 1) was very simple showing an olefinic proton $\left\{\delta_{\mathrm{H}} 5.72(\mathrm{t}, 7.2 \mathrm{~Hz})\right\}$ and six methylene protons $\left\{\delta_{\mathrm{H}} 2.62(\mathrm{q}, 7.2 \mathrm{~Hz}, 2 \mathrm{H})\right.$; $3.25(\mathrm{~s}, 2 \mathrm{H}) ; 3.34(\mathrm{t}, 7.2 \mathrm{~Hz}, 2 \mathrm{H})\}$, while the ${ }^{13} \mathrm{C}$ NMR spectrum (Table 1) revealed the presence of eight carbons. The isolated methylene singlet at $\delta_{\mathrm{H}} 3.25$ in the ${ }^{1} \mathrm{H}$ NMR spectrum had $\mathrm{gHMBC}$ correlations to two carboxylic acid carbonyls $\left\{\delta_{\mathrm{C}} 178.8,174.6\right\}$ and two olefinic carbons $\left\{\delta_{\mathrm{C}} 132.6(\mathrm{~s})\right.$, $139.1(\mathrm{~d})\}$. The proton $\left(\delta_{\mathrm{H}} 5.72\right)$ attached to the olefinic carbon at $\delta_{\mathrm{C}} 139.1$ had a gCOSY correlation to the methylene protons at $\delta_{\mathrm{H}} 2.62$ and these methylene protons $\left(\delta_{\mathrm{H}} 2.62\right)$ had a further gCOSY correlation to the methylene protons at $\delta_{\mathrm{H}}$ 3.34. This information disclosed a 2-pentene-1,2-dicarboxylic acid moiety. The remaining signal to be accounted for was a downfield quaternary carbon at $\delta_{\mathrm{C}} 158.4$ in the 
${ }^{13} \mathrm{C}$ NMR spectrum, which had a chemical shift characteristic for a guanidine carbon. In the gHMBC spectrum there was a correlation between the methylene protons at $\delta_{\mathrm{H}} 3.34$ and the carbon at $\delta_{\mathrm{C}} 158.4$. A guanidine moiety attached to the methylene group at $\delta_{C} 41.8$ in the 2-pentene-1,2-dicarboxylic acid moiety completed the molecular formula revealed by HRESIMS. Now all that remained was to establish whether the olefinic bond was $Z$ or $E$. A ROESY correlation between $\mathrm{H}_{2}-1$ and $\mathrm{H}-3$, confirmed a $Z$ configuration. Therefore, lysianadioic acid was assigned structure 1, (2Z)-2-(3carbamimidamidopropylidene)butanedioic acid.

Lysianadioic acid (1) inhibited $\mathrm{CPB}$ with an $\mathrm{IC}_{50}$ of $0.36 \mu \mathrm{M}$. Based on published data for X-ray structures of small molecule inhibitors in $\mathrm{CPB}$ the following can be predicted about $\mathbf{1}$ in the active site of CPB. ${ }^{10}$ The carboxylic acid, 1-COOH, chelates the Zinc, and the carboxylic acid, 2-COOH, and guanidine group form hydrogen bonds (salt bridges) to Arg145 and Asp255, respectively. Compound 1 is a close mimic to the natural substrate arginine and probably binds in a similar manner.

In conclusion, lysianadioic acid (1), a potent small molecule inhibitor of CPB was isolated from $L$. subfalcata. It is a new arginine analogue containing an unusual dicarboxylic acid moiety and is the first known example of a small molecule CPB inhibitor isolated from plant origin.

\section{Acknowledgments}

We thank AstraZeneca for financial support. We are indebted to Dr. Jennifer Mitchell, Griffith University, Brisbane, for HRESIMS analyses. 


\section{References and notes}

1. Carroll, A. R.; Hyde, E.; Smith, J.; Quinn, R. J.; Guymer, G.; Forster, P. I. J. Org. Chem. 2005, $70,1096$.

2. Bjoerquist, P.; Buchanan, M.; Campitelli, M.; Carroll, A., Hyde, E.; Neve, J.; Polla, M., Quinn, R. PCT Int. Appl., WO 200503961, 2005; Chem. Abstr. 2005, 142, 423904.

3. The plant sample Lysiana subfalcata (Hook.) Barlow (Loranthaceae) was collected at The Pinnacle, Glenlyon Dam-Pinnacle Rd, Darling Downs, Queensland, Australia in February 1994. A voucher sample, AQ600699, was lodged at the Queensland Herbarium, Brisbane, Queensland, Australia.

4. $\quad$ Leary, T.R.; Grahn, D. T.; Neurath, H.; Hass, G. M. Biochemistry 1979, 18, 2252.

5. Rancour, J. M.; Ryan, C. A. Arch. Biochem. Biophys. 1968, 125, 380.

6. Hass, G. M.; Hermodson, M. A. Biochemistry 1981, 20, 2256.

7. Hass, G. M.; Ryan, C. A. Phytochemistry 1980, 19, 1329.

8. $C P B$ Bioassay: Compound in aqueous solution was added to microplates ( $5 \mu \mathrm{L}$ per well). Then to each well was added $50 \mu \mathrm{L}$ of CPB enzyme (0.063 units / $\mathrm{mL})$ in assay buffer (50 mM HEPES, $0.25 \% \mathrm{BSA}, \mathrm{pH} 7.4$ ). The reaction was initiated with addition of $35 \mu \mathrm{L}$ of the chromogenic substrate, anisylazoformyl-L-lysin $(190 \mu \mathrm{M})$ in assay buffer. The plate was incubated at ambient temperature $(\sim 22$ ${ }^{\circ} \mathrm{C}$ ) for $90 \mathrm{~min}$ and the absorbance at $355 \mathrm{~nm}$ was read on a VictorII TM multimode plate reader (Wallac, Turku, Finland).

Percent activity for each compound was determined by the following equation:

$\%$ Activity $=\left[\frac{A b s_{\text {Cmpd }}-A b s_{0 \% \text { Inhibition }}}{A b s_{100 \% \text { Inhibition }}-A b s_{0 \% \text { inhibtion }}}\right] \times 100 \%$ 
Where $0 \%$ inhibition was the absorbance of the full reaction and $100 \%$ inhibition is the absorbance following addition of MGTPA (1 $\mu \mathrm{M}$ final concentration) a carboxypeptidase inhibitor.

9. Lysianadioic Acid (1), (2Z)-2-(3-carbamimidamidopropylidene)butanedioic acid: isolated as an amorphous solid; UV (MeOH) $\lambda_{\max }(\log \varepsilon) 198(3.65) \mathrm{nm}$; IR $v_{\max }\left(\right.$ film) 3452, 1678, 1206, $1140 \mathrm{~cm}^{-1}$; ${ }^{1} \mathrm{H}$ and ${ }^{13} \mathrm{C}$ NMR: see Table 1; positive-HRESIMS $m / z$ z $216.0983\left[\mathrm{C}_{8} \mathrm{H}_{13} \mathrm{~N}_{3} \mathrm{O}_{4}+\mathrm{H}\right]^{+}($calcd 216.0979).

10. Islam, I.; Bryant, J.; May, K.; Mohan, R.; Yuan, S.; Kent, L.; Morser, J.; Zhao, L.; Vergona, R.; White, K.; Adler, M.; Whitlow, M.; Buckman, B. O. Bioorg. Med. Chem. Lett. 2007, 17, 1349. 
Table 1. ${ }^{1} \mathrm{H}(600 \mathrm{MHz}),{ }^{13} \mathrm{C}(125 \mathrm{MHz}), \mathrm{HMBC}$ and COSY NMR data for Lysianadioic acid (1) in $\mathrm{D}_{2} \mathrm{O}^{\mathrm{a}}$

\begin{tabular}{lllll}
\hline Position & $\delta_{\mathrm{C}}$ & $\delta_{\mathrm{H}}(\mathrm{mult}, J \mathrm{~Hz})$ & ${ }^{2,3} J_{\mathrm{CH}} \mathrm{HMBC}(\mathrm{C}$ no. $)$ & COSY (H no. $)$ \\
\hline 1 & $42.7 \mathrm{CH}_{2}$ & $3.25(\mathrm{~s}, 2 \mathrm{H})$ & $1-\mathrm{COOH}, 2-\mathrm{COOH}, 2,3$ & \\
3 & $132.6 \mathrm{qC}$ & & & 4 \\
4 & $139.1 \mathrm{CH}$ & $5.72(\mathrm{t}, 7.2)$ & $2-\mathrm{COOH}, 1$ & 3,5 \\
5 & $29.9 \mathrm{CH}_{2}$ & $2.62(\mathrm{q}, 7.2)$ & $2,3,5$ & 4 \\
1 & $41.8 \mathrm{CH}_{2}$ & $3.34(\mathrm{t}, 7.2)$ & $3,4,2$ & \\
2 & & & & \\
3 & & & & \\
4 & $158.4 \mathrm{qC}$ & & & \\
$1-\mathrm{COOH}$ & $178.8 \mathrm{qC}$ & & & \\
2-COOH & $174.6 \mathrm{qC}$ & & & \\
\hline
\end{tabular}

${ }^{\mathrm{a}} \mathrm{NMR}$ spectra were recorded at $30^{\circ} \mathrm{C}$ on Varian Inova 500 and $600 \mathrm{MHz}$ NMR spectrometers. Samples were dissolved in $\mathrm{D}_{2} \mathrm{O}\left({ }^{1} \mathrm{H}\right)$ or $\mathrm{D}_{2} \mathrm{O}+2 \%$ DMSO $\left({ }^{13} \mathrm{C}\right)$, chemical shifts calculated relative to the solvent peak $\left(\mathrm{D}_{2} \mathrm{O}{ }^{1} \mathrm{H} \delta 4.80\right.$ and DMSO $\left.{ }^{13} \mathrm{C} 39.5 \mathrm{ppm}\right)$. Multiplicity determined by DEPT $(\mathrm{s}=\mathrm{C}, \mathrm{d}=\mathrm{CH}, \mathrm{t}=$ $\mathrm{CH}_{2}, \mathrm{q}=\mathrm{CH}_{3}$ ). Standard parameters were used for the 2D experiments, which included gradient gCOSY, gHSQC $\left({ }^{1} J_{\mathrm{CH}}=140 \mathrm{~Hz}\right)$ and $\mathrm{gHMBC}\left({ }^{\mathrm{n}} J_{\mathrm{CH}}=8.3 \mathrm{~Hz}\right)$. 


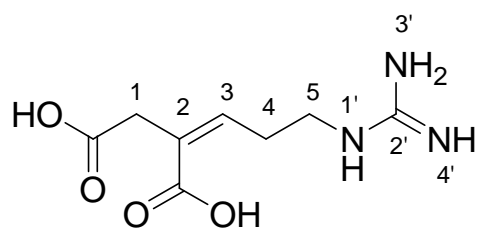

1

Figure 1. Lysianadioic acid (1). 